\title{
Growth Response of Heterobranchus Longifilis Fingerlings Fed Diets Supplemented with Moringa Oleifera Leaf Meal as Replacement of Soybean Meal
}

\author{
Ibiyo Lenient $\mathrm{MO}^{1 *}$, Joshua Felicia $\mathbf{0}^{1}$, Olugbenga Bosede $\mathbf{0}^{2}$ and Azeez Akeem ${ }^{1}$ \\ ${ }^{1}$ Fish Nutrition Programme, National Institute for Freshwater Fisheries Research, P.M.B. 6006, New Bussa, Niger State, Nigeria \\ ${ }^{2}$ Fish Quality Assurance Programme, National Institute for Freshwater Fisheries Research, P.M.B. 6006, New Bussa, Niger State, Nigeria
}

*Corresponding author: Ibiyo Lenient MO, Fish Nutrition Programme, National Institute for Freshwater Fisheries Research, P.M.B. 6006, New Bussa, Niger State, Nigeria.
Received Date: April 29, 2020

Published Date: May 14, 2020

\begin{abstract}
Moringa leaf meal (MLM) is a source of protein from a highly valued plant Moringa oleifera. Its protein has a profile of amino acids similar to that of soybean. A completely randomized design with three replicates was used in a 42 days study to determine digestibility and growth performance of 150 Heterobranchus longifilis fingerlings. Graded levels $(0,5,10,15$ or 20$) \%$ of dried MLM was used to replace soybean meal in a $42.5 \%$ crude protein $\mathrm{H}$. longifilis diet fed at $5 \%$ in the first 2 weeks and subsequently $3 \%$ body weight. The results showed that there were significant differences in weight gain (WG) and specific growth rate (SGR) of the fish with the significant highest observed in the group that fed on diet 2 with $5 \%$ MLM supplementation $(\mathrm{P}<0.05)$ though not significantly different from the control $(\mathrm{P}>0.05)$. The significant poorest WG and SGR were obtained in the group that fed on diet with $20 \%$ level of MLM supplementation $(\mathrm{P}<0.05)$. There was no significant difference between treatments in terms of initial weight, feed intake and survival ( $\mathrm{P}>0.05)$. However there were significant differences in feed conversion ratio (FCR), SGR, total length and standard length among the groups that fed on diets with $15 \%$ and $20 \%$ supplementations $(P<0.05)$. The haematocrit and hemoglobin were also significantly reduced in the group that fed on the highest level of supplementation $(\mathrm{P}<0.05)$. The in-vitro trial revealed significant reduction in digestibility with increase in MLM supplementation level $(\mathrm{P}<0.05)$ the tannin and phytic-acid levels following the same trend. However there was no pathological defect observed in the fish from all the groups. There was no significant difference in the hepathosomatic index. The feed cost analysis showed a reduction in cost per $100 \mathrm{~kg}$ feed with increased level of supplementation with $0.00,11.50,23.20,34.00$ and $50.64 \%$ for diets $1,2,3,4$ and 5 respectively. It was concluded that $5-10 \%$ MLM supplementation could be used in the diets of $H$. longifilis to obtain a reduction in cost of feeding it at $11.2 \%$ and $23.5 \%$ per $100 \mathrm{Kg}$ feed respectively. There is need to try other processing methods if the level could increase above that obtained from this study.
\end{abstract}

Keywords: Heterobranchus longifilis; Moringa leaf meal; Soybean meal; Digestibility and performance

\section{Introduction}

Aquaculture is the fastest growing sector of the world's animal production with an annual increase of about $10 \%$ [1]. To sustain such high rates of increase in production, a matching increase in fish feed production is imperative. Because fish meal is a limited primary source and plants are widely available and reasonably priced, the use of plant protein sources in aqua feeds should be considered [2]. Therefore, in order to attain more economically sustainable, environmentally friendly and viable production, research interest has been directed towards the evaluation and use of non-conventional sources of plant and animal protein. Soybean meal is one of the most nutritious of all plant protein sources because of its high protein content, high digestibility, and relatively well-balanced ami no acid profile [3]. Owing to its reasonable price and steady supply, soybean meal is widely used as a cost-effective feed ingredient for most aquaculture species [4]. It is currently the most commonly used plant protein source in fish feeds [5]. However, soybean meal use in animal feeds competes with human food use, and hence there is a need to identify other protein-rich plant resources that could be used in fish diets. Another potential alternative plant protein source for fish feeds is moringa (Moringa oleifera). This plant is receiving much attention because its leaves, flowers and seeds can all be used as food [6]. Moringa leaf contains crude protein (CP) with about $260 \mathrm{~g} / \mathrm{kg}$ of leaf, of which about $87 \%$ is true protein [7]. Essential amino acids found in moringa leaf are methionine, cyste- 
ine, typtophan and lysine [6]. Analyses of the leaf composition have revealed them to have significant quantities of vitamins $A, B$ and C, calcium, iron and protein. According to Optima of Africa, Ltd., a group that has been working with the tree in Tanzania, "25 grams daily of Moringa Leaf Powder (MLP) will give a child" the following recommended daily allowances: Protein 42\%, Calcium 125\%, Magnesium 61\%, Potassium 41\%, Iron 71\%, Vitamin A 272\%, and Vitamin C $22 \%$. A comparison between the amino acid composition of raw moringa leaf and that of soybean revealed an almost identical pattern of the essential amino acids [8]. There is an abundant total amount of these essential amino acids plenty in the leaf that can be used as animal feed [9]. The objective of this present experiment was to investigate the effect of different levels of dietary moringa leaf meal as a partial replacement of full fat soybean meal in the diet of Heterobranchus longifilis, (giant African catfish) fingerlings on the growth performance, nutrient digestibility, hematology and liver histopathology.

\section{Materials and Methods}

\section{Preparation of Moringa olifera leaf meal (MLM)}

The M. oleifera leaves used in the diets was harvested whole in NIFFR Estate, New Bussa, Niger State and air dried under the shade. The whole leaves harvested were allowed to wilt under the shade overnight after which mere shaking it help the leaflets to drop out of the stalk before final drying. This was to avoid the stalk of the leaves mixing up with the leaflets needed and reduce fibre contribution from the MLM into the diets. The leaflets were milled to powder after they have properly dried which was used for the preparation of the experimental diets (Plate 1).

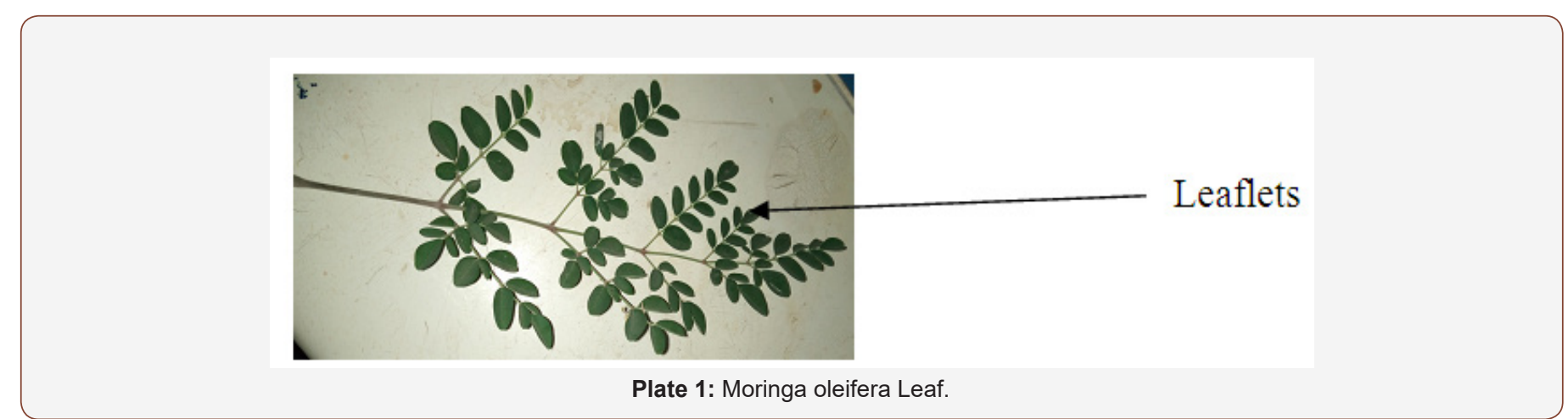

\section{Experimentation}

Three Hundred Heterobranchus longifilis fingerlings were acquired and acclimatized for three weeks before selection and subjection to the experiment. Completely randomized design with three replicate groups was used to study the response of $150 \mathrm{Het}$ erobranchus longifilis fingerlings to diets supplemented with graded levels $(0,5,10,15$ or 20)\% of Moringa leaf meal (MLM) to replace soybean meal in a soybean and fish meal based diet together with other ingredients (Table 1 ). The 42 days study was carried out in an aerated aquaria using indoor at the fish nutrition laboratory in NIFFR feed mill complex. Diet 1 with a zero supplementation served as control. Chemical analysis such as phytochemicals in leaf considering tannin and phytic acid determination, proximate composition (AOAC, 2000), hematology, histopathology of feed and fish

Table 1: Composition of $42.5 \%$ Crude Protein Experimental diet. samples were carried out. Digestibility was also assessed. Fish were fed at $5 \%$ body weight at commencement of the study in the first 2 weeks but was reduced to $3 \%$ body weight when much leftover feeds were observed which could be due to Heterobranchus feed consumption nature which is poor. The daily rations were divided into two installments, supplied morning (8.00 - $9.00 \mathrm{am})$ and evening $(6.00-7.00 \mathrm{pm})$. Siphoning of the bottom of the aquaria was carried out each morning and addition of freshwater to maintain water level before feeding the fish. Fortnight sampling was adopted for feed adjustments, fish observation and total cleaning of the aquaria. Water quality was monitored in the course of the study using easy test kit. Feed cost was calculated based on the prevailing market prices of the ingredients at the period of experimentation. Statistical analysis was carried out on the data obtained at the end of the study.

\begin{tabular}{|c|c|c|c|c|c|}
\hline Ingredients & Diet 1 & Diet 2 & Diet 3 & Diet 4 & Diet 5 \\
\hline Moringa leaf meal & 0 & 5 & 10 & 15 & 20 \\
\hline Full fat soybean meal & 20 & 15 & 10 & 5 & 0 \\
\hline Fishmeal & 25 & 25 & 25 & 25 & 25 \\
\hline Groundnut cake & 35.87 & 37.53 & 38.9 & 40.26 & 41.62 \\
\hline Maize bran & 11.33 & 9.67 & 8.3 & 6.94 & 5.58 \\
\hline Starch & 2 & 2 & 2 & 2 & 2 \\
\hline Palm oil & 2 & 2 & 2 & 2 & 2 \\
\hline Bone meal & 2 & 2 & 2 & 2 & 2 \\
\hline Premix* & 0.5 & 0.5 & 0.5 & 0.5 & 0.5 \\
\hline
\end{tabular}




\begin{tabular}{|c|c|c|c|c|c|}
\hline Methionine & 0.5 & 0.5 & 0.5 & 0.5 & 0.5 \\
\hline Lysine & 0.5 & 0.5 & 0.5 & 0.25 & 0.5 \\
\hline Salt & 0.25 & 0.25 & 0.25 & 0.02 & 0.25 \\
\hline B-complex & 0.02 & 0.02 & 0.02 & 0.03 & 0.02 \\
\hline Vitamin C & 0.03 & 0.03 & 0.03 & 100 & 0.03 \\
\hline Total & 100 & 100 & 100 & 100 \\
\hline
\end{tabular}

*Provides per kg diet: Vitamin A, 125000 IU, Vitamin D3 2500 IU, Vitamin E 40mg, Vitamin K 2mg; Vitamin B1 3mg; Vitamin B2 5.5mg; Choline chloride 500mg; Niacin 35mg; Vitamin B6 5mg; Vitamin B12 0.025mg; Folic acid 1mg; Biotin 0.08mg; Manganese 120mg; Iron 100mg; Zinc 80mg; lodine 1.8 mg; Calcium pantothenate 11.5mg; Copper 8.5mg; Cobalt $0.3 \mathrm{mg}$; Selenium $0.12 \mathrm{mg}$; vitamin C 2000mg, Antioxidant $120 \mathrm{mg}$;

\section{In-Vitro protein digestibility}

The experimental diets were measured in triplicates by cleavage peptides [10]. $20 \mathrm{mg}$ of each diet was added with $12 \mathrm{ml}$ of $50 \mathrm{mM}$ phosphate buffer ( $\mathrm{pH} 7.5$ ) and incubated overnight at 30 ${ }^{\circ} \mathrm{C}$. In-vitro digestion was started by adding $500 \mu \mathrm{l}$ of crude enzyme extract and incubated for 24 hours at $30^{\circ} \mathrm{C}$. After digestion, $1 \mathrm{ml}$ of each digested mixture was determined of cleavage peptides by measuring absorption at $750 \mathrm{nM}$ and converted into mg protein using a standard curve developed from the principle reported by [11].

\section{Results}

The results of diets' proximate composition, growth performance, in-vitro digestibility, and antinutritional factors in the diets are presented in the tables 2-5 below. The growth performance results showed that there was significant difference in weight gain of the fish with the significant highest gain observed in the group that fed on diet 2 with $5 \%$ supplementation $(\mathrm{P}<0.05)$. The significant poorest weight gain was obtained in the group that fed on diet 5 with highest $(20 \%)$ level of MLM supplementation $(\mathrm{P}<0.05)$. There was no significant difference between treatments in terms of initial weight, feed fed and survival $(\mathrm{P}>0.05)$. However there was signifi- cant difference in FCR, Specific growth rate, total length and standard length among the groups that fed on diets 4 and 5 with $15 \%$ and $20 \%$ supplementations respectively $(\mathrm{P}<0.05)$. The significant poorest specific growth rate (SGR) was observed with the group that fed on the highest MLM supplementation $(\mathrm{P}<0.05)$ while the significant highest SGR was obtained with the groups that fed on 5\% MLM supplementation though it was not significantly different from the control group. The haematocrit and haemoglobin were also significantly reduced in the group that fed on the highest level of supplementation $(\mathrm{P}<0.05)$. The in-vitro trial revealed significant reduction in digestibility with increase in MLM supplementation level $(\mathrm{P}<0.05)$. The tannin and phytic-acid levels followed the same trend. However there was no pathological defect observed in the fish from all the groups. There was no significant difference in the hepathosomatic index. The cost analysis showed a reduction in cost per $100 \mathrm{~kg}$ feed with increased level of supplementation with 0.00 , $11.50,23.20,34.00$ and $50.64 \%$ for diets $1,2,3,4$ and 5 respectively. The results of the water qualities monitored have means falling within the range suitable for good growth of catfish with temperature $27.5^{\circ} \mathrm{C}$, dissolved oxygen $4.6 \mathrm{mg} / \mathrm{l}, \mathrm{pH} 7.51, \mathrm{NH}_{3}-\mathrm{N} 0.34 \mathrm{mg} / \mathrm{l}$ and $\mathrm{NH}_{2}-\mathrm{N} 0.026 \mathrm{mg} / \mathrm{l}$ (Table 2 - Table 5).

Table 2: Composition of $42.5 \%$ Crude Protein Experimental diet.

\begin{tabular}{|c|c|c|c|c|c|}
\hline Parameters & Diet 1 & Diet 2 & Diet 3 & Diet 4 & Diet 5 \\
\hline Moisture Content \% & 6.02 & 6.08 & 5.89 & 6.55 & 6.01 \\
\hline Crude Protein \% & 44.78 & 42.69 & 42.56 & 41.89 & 41.69 \\
\hline Crude Fat \% & 13.5 & 13.35 & 13.89 & 12.73 & 12.05 \\
\hline Crude Fibre\% & 2.02 & 2.41 & 3.54 & 4.98 & 7.02 \\
\hline Ash \% & 7.65 & 7.77 & 7.82 & 7.89 & 7.65 \\
\hline NFE \% & 26.03 & 27.7 & 27.3 & 25.96 & 26.58 \\
\hline
\end{tabular}

Table 3: Growth performance of Heterobranchus longifilis fingerlings fed diets with graded level of MLM as replacement for toasted full fat soybean meal $(0-6$ weeks).

\begin{tabular}{|c|c|c|c|c|c|}
\hline Parameter & Diet 1 & Diet 2 & Diet 3 & Diet 4 & Diet 5 \\
\hline Initial Weight (g/Fish) & $9.25 \pm 0.34 \mathrm{a}$ & $9.14 \pm 0.55 \mathrm{a}$ & $8.96 \pm 0.22 \mathrm{a}$ & $8.61 \pm 0.16 \mathrm{a}$ & $9.11 \pm 0.41 \mathrm{a}$ \\
\hline Weight Gain (g /Fish) & $16.14 \pm 0.70 \mathrm{ab}$ & $23.63 \pm 12.76 \mathrm{a}$ & $16.41 \pm 5.61 \mathrm{ab}$ & $16.71 \pm 4.81 \mathrm{ab}$ & $8.54 \pm 3.36 \mathrm{c}$ \\
\hline Feed Consumed (g/Fish) & $15.50 \pm 3.45 \mathrm{a}$ & $22.45 \pm 13.31 \mathrm{a}$ & $16.37 \pm 8.04 \mathrm{a}$ & $17.38 \pm 16.06 \mathrm{a}$ & $10.33 \pm 3.9 \mathrm{a}$ \\
\hline Feed Conversion Ratio & $0.96 \pm 0.14 \mathrm{a}$ & $0.93 \pm 0.05 \mathrm{a}$ & $1.00 \pm 0.10 \mathrm{a}$ & $0.97 \pm 0.15 \mathrm{a}$ & $1.2 \pm 0.02 \mathrm{~b}$ \\
\hline SGR (\%/day) & $2.38 \pm 0.05 \mathrm{ab}$ & $2.90 \pm 0.94 \mathrm{a}$ & $2.45 \pm 0.55 \mathrm{ab}$ & $2.53 \pm 0.44 \mathrm{ab}$ & $1.54 \pm 0.46 \mathrm{~b}$ \\
\hline Survival (\%) & $70.00 \pm 00 \mathrm{a}$ & $45.83 \pm 36.08 \mathrm{a}$ & $66.67 \pm 14.43 \mathrm{a}$ & $58.33 \pm 28.86 \mathrm{a}$ & $66.67 \pm 14.43 \mathrm{a}$ \\
\hline Total Length (Cm) & $9.70 \pm 0.26 \mathrm{~b}$ & $10.78 \pm 0.89 \mathrm{a}$ & $10.55 \pm 0.26 \mathrm{ab}$ & $9.75 \pm 0000 \mathrm{~b}$ & $10.21 \pm 0.40 \mathrm{ab}$ \\
\hline Standard Length (Cm) & $8.00 \pm 0.00 \mathrm{c}$ & $9.10 \pm 0.81 \mathrm{a}$ & $8.88 \pm 0.43 \mathrm{ba}$ & $8.25 \pm 0.00 \mathrm{c}$ & $8.77 \pm 0.25 \mathrm{ba}$ \\
\hline Haematocrit (\%) & $23.76 \pm 1.16 \mathrm{a}$ & $24.35 \pm 1.05 \mathrm{a}$ & $24.67 \pm 1.17 \mathrm{a}$ & $23.86 \pm 2.66 \mathrm{a}$ & $19.02 \pm 1.23 \mathrm{~b}$ \\
\hline
\end{tabular}




\begin{tabular}{|c|c|c|c|c|c|}
\hline Haemoglobin (mg/dl) & $11.20 \pm 2.32 \mathrm{a}$ & $11.05 \pm 2.15 \mathrm{a}$ & $11.40 \pm 2.20 \mathrm{a}$ & $10.80 \pm 1.20 \mathrm{a}$ & $7.02 \pm 2.34 \mathrm{~b}$ \\
\hline $\begin{array}{c}\text { \% Reduction in N/100Kg } \\
\text { Feed }\end{array}$ & 0 & 11.5 & 23.2 & 34 & 50.64 \\
\hline
\end{tabular}

${ }_{a-c}$ Means plus standard deviation within rows with different superscript(s) significantly different $(P<0.05)$. SGR = Specific growth rate.

Table 4: Phytochemical contents of Moringa leaf and experimental diets.

\begin{tabular}{|c|c|c|c|c|c|c|}
\hline Parameters \% MLM & Moringa leaf & Diet 1 & Diet 2 & Diet 3 & Diet 4 & Diet 5 \\
\hline Total Tannin & $2.82 \pm 0.69$ & $0.82 \pm 0.06 \mathrm{c}$ & $2.09 \pm 0.27 \mathrm{~b}$ & $2.36 \pm 0.12 \mathrm{ab}$ & $2.51 \pm 0.28 \mathrm{a}$ & $2.60 \pm 0.24 \mathrm{a}$ \\
\hline Phytic acid & $0.49 \pm 0.14$ & $0.46 \pm 0.05 \mathrm{c}$ & $1.15 \pm 0.13 \mathrm{~b}$ & $1.29 \pm 0.05 \mathrm{ab}$ & $1.40 \pm 0.13 \mathrm{a}$ & $1.48 \pm 0.14 \mathrm{a}$ \\
\hline
\end{tabular}

${ }_{\mathrm{a}-\mathrm{c}}$ Means plus standard deviation within rows with different superscript(s) significantly different $(\mathrm{P}<0.05)$.

Table 5: Digestibility of the Diets fed to Heterobranchus longifilis fingerlings ( 0 - 6weeks).

\begin{tabular}{|c|c|c|c|c|c|}
\hline Parameters & Diet 1 (Control) & Diet 2 & Diet 3 & Diet 4 & Diet 5 \\
\hline Digestibility coefficient (\%) & $83.65 \pm 1.59 \mathrm{a}$ & $79.29 \pm 0.36 \mathrm{a}$ & $75.05 \pm 1.25 \mathrm{~b}$ & $71.45 \pm 1.78 \mathrm{~b}$ & $68.34 \pm 1.68 \mathrm{c}$ \\
\hline Protein digestibility (\%) & $92.67 \pm 0.55 \mathrm{a}$ & $91.24 \pm 0.43 \mathrm{a}$ & $91.37 \pm 34 \mathrm{a}$ & $88.26 \pm 0.27 \mathrm{~b}$ & $86.39 \pm 0.23 \mathrm{c}$ \\
\hline
\end{tabular}

${ }^{a-c}$ Means plus standard deviation within rows with different superscript significantly different $(P<0.05)$.

\section{Discussions}

The results of this study indicated that $M$. olifera leaves possess the potential to partially replace soybean meal in any soybean and fishmeal base diet for giant African catfish (H. longifilis) without adversely affecting growth performance, digestibility and pathology of the fish. This is in agreement with earlier studies on Oreochromis niloticus by Richter et al. [12] and Abo-State et al. [13] who used MLM to replace fishmeal in the diets of the fish and found out that MLM could replace fishmeal up to $10 \%$ and $8 \%$ respectively in tilapia. Moringa leaf meal (MLM) could be used to reduce pressure on soybean meal. Hardy 2010 noted that soybean is currently the most commonly used plant protein sources in fish feed and there is competition with human use. Using MLM to reduce pressure on soybean will be possible because comparison between the amino acids of MLM and soybean revealed an almost identical pattern of all the essential amino acids [8]. The observation of reduced growth performance, digestibility and poorer FCR at higher inclusion level in this present study is an indication that there is a limit to the extent which MLM could be included in the diet of giant African catfish to avoid negativity in performance. This is similar to what was earlier reported on 0 . niloticus [12,13]. The poor performance at higher levels might not be unconnected to the antinutritional factors present in the raw moringa leaf. Although the MLM used in this study was air dried before use, the phytochemical analysis revealed that the phytic acids and tannin were still present in the diets though at low levels. The poor performance observed in the groups that fed on diets with higher inclusion levels of MLM might be related to the likely interaction of the antinutritional factors with utilization of other nutrients in the feeds [6]. The poor $\mathrm{Hb}$ and PCV levels obtained in the groups that fed on the highest MLM supplementation level might have been due to interactive effect of phytochemicals against the fish natural body functional ability to neutralize or suppress the deleteriousness of certain ingested chemicals. The appreciable digestibility of protein obtain in this study might be due to the drying process the leaf undergo before its use, the equal fishmeal levels and palm oil as a source of lipids in the diets with the fact that it is plant protein portion that was replaced. Palm oil has a natural tendency to neutralize the efficacy of poisonous substances like the one that could result from the antinutritional factors such as the tannins and phytic substances in the MLM. It had also been noted that antinutrients such as tannins and saponins inflicts bitterness in feeds and could results in poor consumption [2] due to reaction of the chemosensory receptors [14]. That might happen at high levels of inclusion which could result to high concentration of those antinutrients and subsequent effective bitterness since the intake in this study did not exhibit such criteria as there was no significant difference in feed intake. Although increased level resulted into poor feed conversion ratio which might not be unconnected to the carnivorous-ominivorous nature of the giant African catfish and tannins interaction with utilization of nutrients in feeds. The effective cost reduction also observed in the formulations with MLM is an indication that it could be used to replace some soybean in the diets of giant African catfish at the optimum level of 5-10\% replacement.

In conclusion, MLM could be used to partially replace up to 5 - $10 \%$ of the full fat soybean meal in the diet of giant African catfish, Heterobranchus longifilis fingerlings without reduction in the growth performance of the fish. The MLM use will also lead to reduction in cost of fish feed. Using the best performing supplementation level (5\%) will result to a cost reduction of $11.5 \%$ per cost of $100 \mathrm{Kg}$ feed base on the formulations used in this study while the $10 \%$ optimum level of supplementation will result to feed cost reduction of $23.2 \%$ per cost of $100 \mathrm{Kg}$ feed [15]. The cost to benefit ratio obtained in the study encourages the use of 5\% level of replacement. There is need to subject moringa leaves to other processing methods for another trial to see if there could be improvement from what was obtained in this present study. There is need to evaluate the response of Clarias species to moringa leaf inclusion in the diet.

\section{Acknowledgement}

None.

\section{Conflict of Interest}

No conflict of interest. 


\section{References}

1. Food and Agricultural organization FAO (1997) Fisheries Improvement by Stocking at High Altitudes for Inland Development (FISHAID) Project, Papua New Guinea. FI: PNG/93/007 Terminal Report, Rome.

2. State of World Fisheries and Aquaculture (2006) FAO Fisheries Technical Paper. No. 500. Rome, Italy.

3. Lovell RT (1988) Use of soybean products in diets for aquaculture species. Journal of Aquaculture Production 2: 27-52.

4. Storebakken T, Refstie S, Ruyter B (2000) Soy products as fat and protein sources in fish feeds for intensive aquaculture. JK Drackley (Ed.), Soy in Animal Nutrition. Federation in Animal Science Societies. Savoyy, IL, USA, Pp. 127-170.

5. Hardy RW (2010) Utilization of plant proteins in fish diets: Effect of global demand and supplies of fishmeal. Journal of Aquaculture Research 41(5): 770-776.

6. Makkar HPS, Becker K (1996) Nutritional value and antinutritional compounds of whole and ethanol extracted Moringa oleifera leaves. Animal Feed Science and Technology 63: 211-228.

7. Makkar HPS, Becker K (1997) Nutrients and antiquality factors in different morphological parts of the Moringa oleifera tree, Journal of Agricultural Science 128: 311-332.

8. Foidl NH, Makkar PS, Becker K (2001) The potential of Moringa oleifera for agricultural and industrial uses LJ Fuglie (Ed.), The Miracle Tree, CTA and CWS, Senegal, pp. 45-77.
9. Afuang W, Siddhuraju P, Becker K (2003) Comparative nutritional evaluation of raw, methanol extracted residues and methanol extracts of moringa (Moringa oleifera Lam.) leaves on growth performance and feed utilization in Nile tilapia (Oreochromis niloticus L.). Aquaculture Research 34: 1147-1159.

10. Gimenneze AVF, Fernandez I, Preciado RM, Oliva M, Tova D, et al. (1999) The activities of digestive enzyme during the molting stage of the arche swimming Callinectes arcautus or day, 1863. Bulletin of Marine Science 65: $1-9$.

11. Lowry OH, Rosebrough NS, Farr AL, Randall RS (1951) Protein measurement with the Folin Phenol reagent. The Journal of Biological Chemistry 193: 265-275.

12. Richter N, Siddhurraju P, Becker K (2003) Evaluation of nutritional quality of moringa (Moringa oleifera Lam.) leaves as alternative protein source for tilapia (Oreochromis niloticus L.). Aquaculture 217: 599-611.

13. Abo-State MA, Ragab AME, Nour Sh El-Gendy, Farahat LA, Madian HR (2014) Bioethanol production from rice straw enzymatically saccharified by fungal Isolates, Trichoderma viride F94 and Aspergillus terreus F98. Soft 3: 19-29.

14. Madalla N (2008) Novel feed ingredients for Nile tilapia (Orechromis niloticus L.). In: PhD Thesis, Inst. Aquaculture, Univ. Stirling, Scotland, UK. Pp. 196.

15. AOAC (2000) Association of Official Analytical Chemists. 17th Edition, A.O.A.C, Washington DC. Pp. 21,447. 